\title{
海域締切り工事における流れの数值解析と施工検討
}

Investigation into construction process at the works bulkhead based on numerical flow analysis

\author{
平岡順次* · 澄川 健 $* *$. 中下明文*** \\ Jyunji Hiraoka,Tuyoshi Sumikawa,Akifumi Nakasita \\ 田坂友次郎 $* * * *$. 北崎義隆 $* * * *$. 永瀬恭一 $* * * * *$ \\ Tomojiro Tasaka, Yoshitaka Kitazaki,Kyoichi Nagase
}

\begin{abstract}
In harbor entrances, a rapid currents sometimes happen with large-scale vortex by tidal waves and harbor oscillation. As the harbor entrance narrow down with construction works, the same current is expected. From the point of view, an investigation was necessary to ensure safe works, at the works of bulkhead for ash disposal in the Misumi thermal power plant.

In the beginning, we observed water velocities and surface variations for the investigation and the analysis. As a result, we can get surface variations due to 13 minutes period waves. We thought that these waves caused the rapid current. Then, we calculated water velocities at every step of works by method of shallow water equation, and evaluated the process of construction.
\end{abstract}

Key words : harbor oscillation, bulkhead, shallow water equation, construction.

1.はじめに

港湾の入口では、潮汐や湾水振動 等によって、しばしば大規模な渦を 伴う速い流れの発生することが知 られており（例えば、中山ほか （1994））、港湾工事などの施工過 程においても港口が狭くなるにし たがって同様の流れが発生するこ とが予測される。中国電力三隅火力 発電所の灰捨場護岸工事において も、最終締切り箅所で 5 ノット程度 の流速が観測され、締切り工事の安 全性が問題となった。

そこで、施工前の流況や水位の変 化を観測し、施工検討や解析に利用

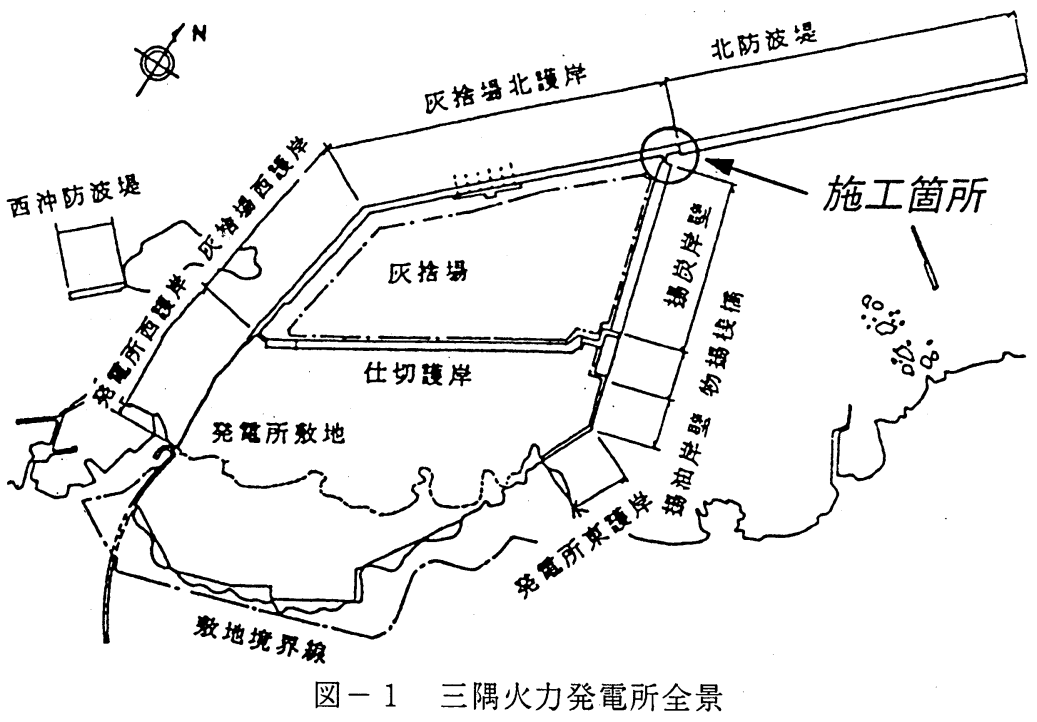
するデータの取得を試みた。その結果、流れと同時にその原因と推測される 13 分程度の長周期水面変動を観測す ることができた。この水面変動のデータを用いて数值解析を行い、各施工段階の流速を予測して施工方法の検討 を行った。また、施工に際して再び現地観測を行い、解析值との比較を行った。

\section{2. 工事概要と問題点}

三隅火力発電所は、島根県西部の日本海に面して立地する石炭専焼火力発電所（1 号機：100 万 kW、2 号機： 40 万 $\mathrm{kW}$ ) である。発電所用地の造成工事は昭和 61 年 10 月に着手しており、平成 10 年 7 月に 1 号機の営業運転 を開始する予定である。運転に伴って発生する石炭灰は、発電所敷地に隣接した海域の管理型灰捨場に処分する 計画で、その面積は約 32 万 $\mathrm{m}^{2}$ を有する。当工事は、図ー1に示すような兏捨場を最終的に外海と隔離する締切り 工事である。図ー 2 に示すように、ケーソン 4 基（No.96 99）、ケーソンと鋼板セルを連結するアーク 2 枚を据 付ける。既設ケーソンと当工事によって据付けるケーソンとの接合部は、水中コンクリートエによって海域の締

\footnotetext{
* 正会員 中国電力 (株) 三隅発電所建設所 土木課 課長（現、中国電力 (株) 土木部 課長代理)

** 正会員 中国電力(株) 三隅発電所建設所 土木建築課 副長

*** 正会員 中国電力 (株) 三隅発電所建設所 土木建築課 係長

**** 正会員 (株) フジタ 広島支店 土木部

***** 正会員 (株) フジタ 技術研究所 土木研究部（テ224 神奈川県横浜市都筑区大棚町 74）
} 
切りを行う。

ケーソン据付け工事に先立つ捨石基礎の 造成中に、工事箇所を横断する速い流れが 発生して潜水作業が不可能となり、度々工 事の中断を余儀なくされた。ケーソン設置 などの工事の進渉に伴って、開口部が縮小 によって流速の増加が予測され、工事の安 全性と施工性が問題となった。

\section{3. 現地観測}

施工検討を行うに当たり、現地観測を行 った。まず、周辺の水位の時間変化と流速 の関係を調べることを目的とした短期観測 (平成 7 年 6 月 15 日 16:00 16 日 24:00) を行った。その後、速い流れの発生頻度を 調べ、波浪や気象条件との関係を検討 するため、約 2 週間の長期観測（平成 7 年 6 月 17 日〜 7 月 3 日）を行った。水 位は既設のケーソンに容量式波高計を 固定して観測した。また、流速は鋼管 杭および既設ケーソンに固定した電磁 流速計とメモリパック式流速計を用い て観測した。なお、長期観測は短期の 観測が終了した時点で S T 1 の流速計 の設定を変更して行った。観測位置お よび観測内容は図ー 2 と表ー 1 に示す。

\section{1 短期観測結果}

短期観測を行った 32 時間の観測期間の内、流速 と水位が周期的に変動した 1995 年 6 月 16 日 18:00 〜20:00 のデータを図ー 3 に示す。水位変動は 0.5 秒、流速は 1 秒間隔で観測しており、各々30 秒間 のデータを平均して、風波など影響を除夫した。

図一 3 (a)のH 1 は締切りの内側水位、H 2 は外 側の水位である。同図からこの時間帯は潮汐によ って水位が平均水面より下がり始めた段階である ことが分かる。潮汐による水位の低下とともに、 約 13 分の周期で $10 \mathrm{~cm}$ 程度の振幅が見られる。こ の振幅が、問題となっている流れの大きな原因と 考えられる。

灰捨場内の平均的な水深 $h$ を $10 \mathrm{~m}$ とすると、波 長が水深に比べ十分長い浅水長波の波速 C は $C=\sqrt{g h}=9.9 \mathrm{~m} / \mathrm{s}$ となる。灰捨場の形状を長方形(長 辺方向の奥行き $L \doteqdot 1,200 \mathrm{~m})$ と仮定して、固有周 期 $T$ を概算すると $T=2 L / C=240$ 秒となる。しかし、 観測された水面変動はその 3 倍以上の周期を持つ。 したがって、流れの原因は灰捨場内の固有振動に よる水面変動ではなく、もう少し広い海域の固有 振動による水位変動などが原因と考えられる。

次に図ー3(b)〜 (d)の流速に注目する。 S T 1 は水面下 $5 \mathrm{~m} 、 \mathrm{~S} \mathrm{~T} 2$ は水面下 $2 \mathrm{~m}$ の同一鋼管杭

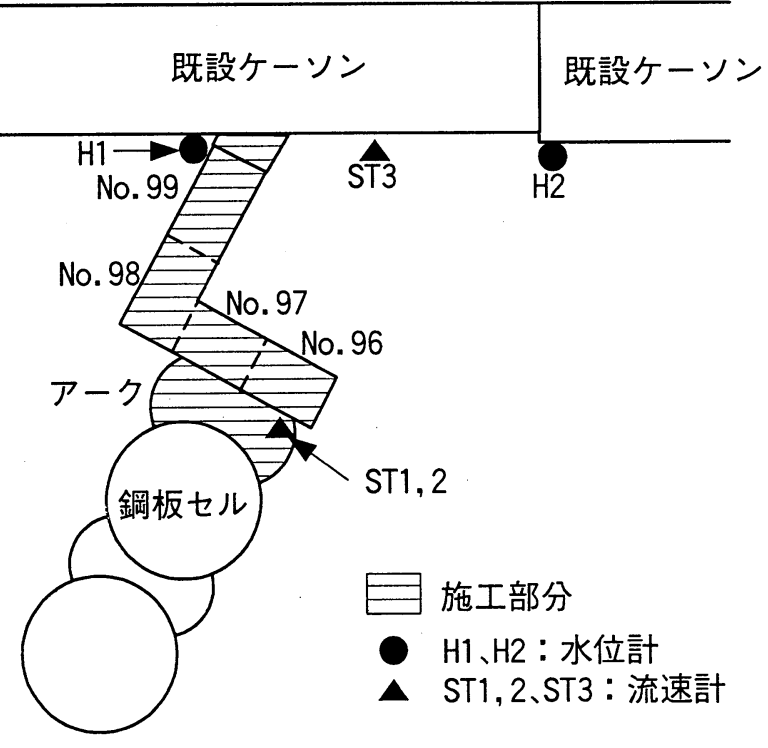

図一 2 工事䇢所詳細

表 -1 観測機器

\begin{tabular}{|c|c|c|c|c|}
\hline 期間 & 測点 & 設置水深 & 計測器 & サンプリング間隔 \\
\hline \multirow{2}{*}{ 短期 } & $\mathrm{H} 1$ & & 容量式波高計 & $0.5 \mathrm{sec}$ \\
\hline & $\mathrm{H} 2$ & & 容量式波高計 & $0.5 \mathrm{sec}$ \\
\hline 長/短期 & $\mathrm{S} \mathrm{T} 1$ & $.5 \mathrm{~m}$ & メモリーパック式 & $5 \mathrm{~min} . / 1.0 \mathrm{sec}$ \\
\hline \multirow{2}{*}{ 短期 } & $\mathrm{S} \mathrm{T} 2$ & $-2 \mathrm{~m}$ & 電磁流速計 & $1.0 \mathrm{sec}$ \\
\hline & $\mathrm{ST} 3$ & $-2 \mathrm{~m}$ & 電磁流速計 & $1.0 \mathrm{sec}$ \\
\hline
\end{tabular}
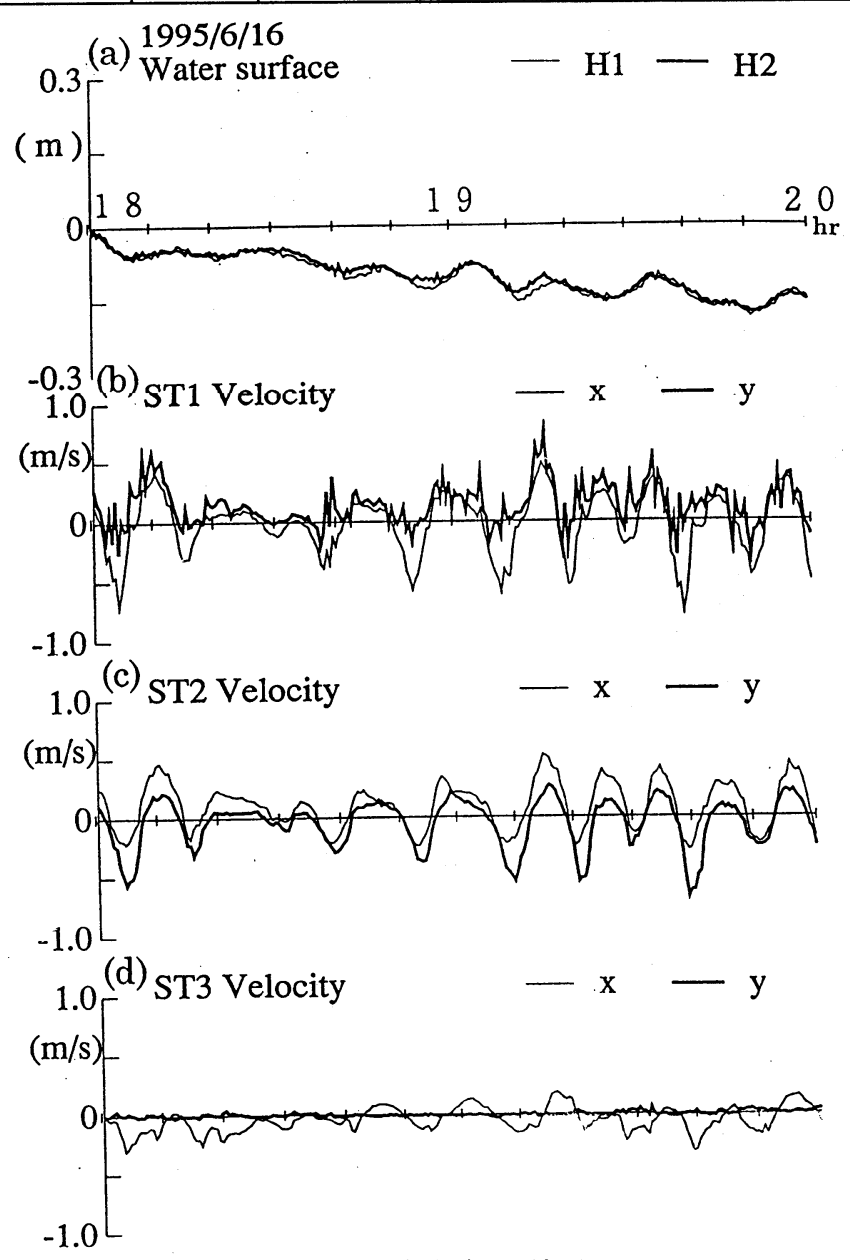

図-3 短期観測結果 
に設置して 2 層の流れを観測 している。また、ST 3 は北 護岸の前面 $1 \mathrm{~m}$ の地点に設置 されている。図ー3(b)，(c) よれば、水面変動と同周期で $0.5 \mathrm{~m} / \mathrm{s}$ 程度の流速が観測さ れている。流速計を鋼管杭に 金物で固定しているため、流 速が速くなると鋼管杭による 渦が発生して流速に乱れがみ られる。ST 2 の流速に比較 してST1の流速の乱れが大 きいのは、電磁流速計の時定 数の違いによるものと考えら れる。この 2 点の流速の時間

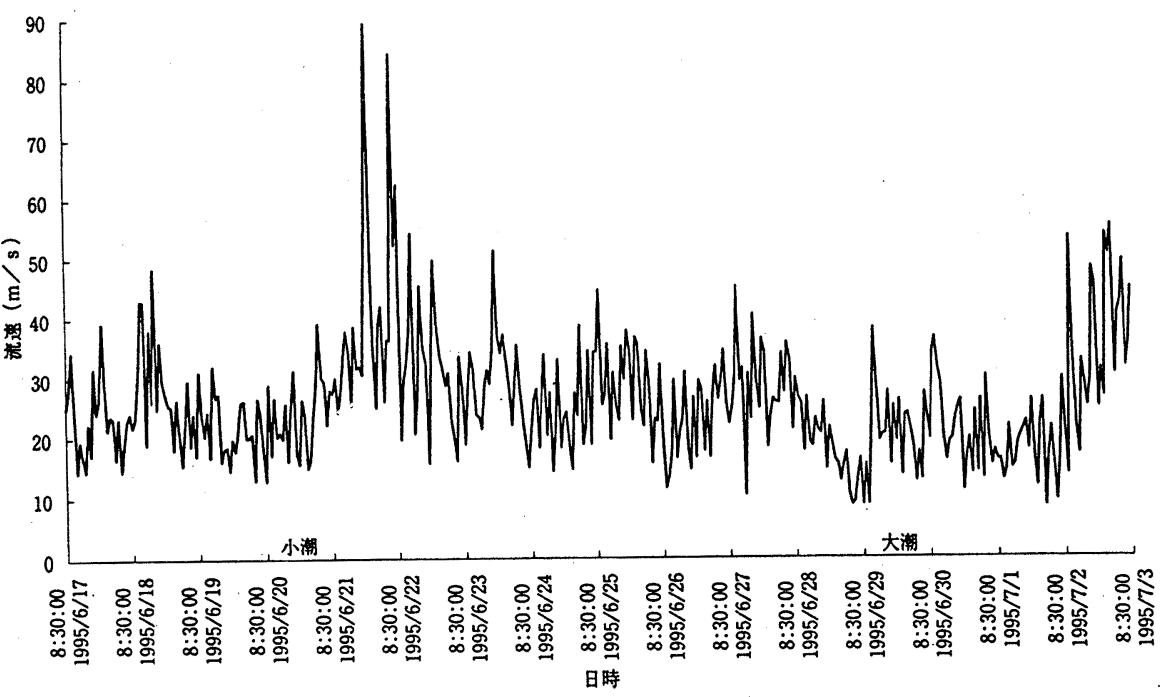

図一 4 長期観測結果

変化はほとんど同じ位相で推移しており、その大きさもほぼ一致している。一方、図ー3(d)に示す S T 3 の流速 に注目すれば、S T 1、S T 2 と比較すると振幅は小さいが、同じ位相で時間変化していることがわかる。

\section{2 長期観測結果}

16 日間の観測期間中、S T 1 の流速計で 5 分毎に 1 分間の観測を行った。その絶対值を一時間ごとに平均し て図ー4にプロットした。平均的に $0.25 \mathrm{~m} / \mathrm{s}$ 程度の流わが続いており、時折なにかの原因によって流速が速くな る時があることがわかる。ケーソン設置などの作業を行うにあたって、この $0.25 \mathrm{~m} / \mathrm{s}$ 程度の流速は避けることが できず、それ以上の流速が発生する場合には海象の変化に十分注意をして施工を進める必要があると思われる。 また、この観測期間中 6 月 20 日に小潮、2 9 日に大潮を観測しているが、この時にも特に大きな変化は観測さ れておらず、潮汐と流速との明確な相関は認められない。また、同期間に周辺で別に観測された波浪のデー夕に よると、波高・周期ともに安定しており、波浪との相関も見られない。したがって、短期観測により把握された 周期約 13 分の水面変動が、速い流れの原因と考えられる。

\section{4. 流れの数值解析と施工検討}

\section{1 検討モデル}

施工計画で提案された施工順序を図ー 5 に示す。数值解析はケーソン据付け前の状況と、図ー 5 の(1), (2), (3), (5)の場合について数值解析を行った。実際にはこのほか、ケーソンならびにアークの施工順序を変えた、数ケー スの施工順序についても解析を行ったが、ここでは紙面の都合で省略する。

\section{2 数値解析方法}

圧力を静水圧分布としコリオリカを無視すると、長周期の水面変動による流れの連続式と運動方程式は、以下 のとおりに表される。

$$
\text { 連 続 式: } \frac{\partial \eta}{\partial t}+\frac{\partial}{\partial x}[(h+\eta) U]+\frac{\partial}{\partial y}[(h+\eta) V]=0
$$

運動方程式：

$$
\frac{\partial U}{\partial t}+U \frac{\partial U}{\partial x}+V \frac{\partial U}{\partial y}+g \frac{\partial \eta}{\partial x}=A_{h}\left(\frac{\partial^{2} U}{\partial x^{2}}+\frac{\partial^{2} U}{\partial y^{2}}\right)+\frac{g n^{2} U \sqrt{U^{2}+V^{2}}}{(h+\eta)^{7 / 3}}
$$

$$
\frac{\partial V}{\partial t}+U \frac{\partial V}{\partial x}+V \frac{\partial V}{\partial y}+g \frac{\partial \eta}{\partial y}=A_{h}\left(\frac{\partial^{2} V}{\partial x^{2}}+\frac{\partial^{2} V}{\partial y^{2}}\right)+\frac{g n^{2} V \sqrt{U^{2}+V^{2}}}{(h+\eta)^{7 / 3}}
$$

ここに、 $\mathrm{h}$ : 水深、 $\eta:$ 平均水位、 $\mathrm{U}, \mathrm{V}: \mathrm{x}, \mathrm{y}$ 方向の水深平均流速、 $\mathrm{g}:$ 重力加速度、 $A_{h}:$ 水平方向の渦動 粘性係数、 $\mathrm{n}$ : マニングの粗度係数である。渦動粘性係数と粗度係数に関しては、田中・和田(1985)などを参考 に数ケースの試計算を行い、 $A_{h}=5.0 \times 10^{4} \mathrm{~cm}^{2} / \mathrm{s} 、 \mathrm{n}$ は捨石上を 0.03 としてその他の海域については 0.01 を用 いた。また、壁面の条件はスリップとした。

現地観測によれば、締切り工事で問題となっている流れは、13分程度の長周期の水面変動が原因と考えられる。 そこで、この水面変動を入力とし、以下のような手順で各施工段階における流速を計算した。 


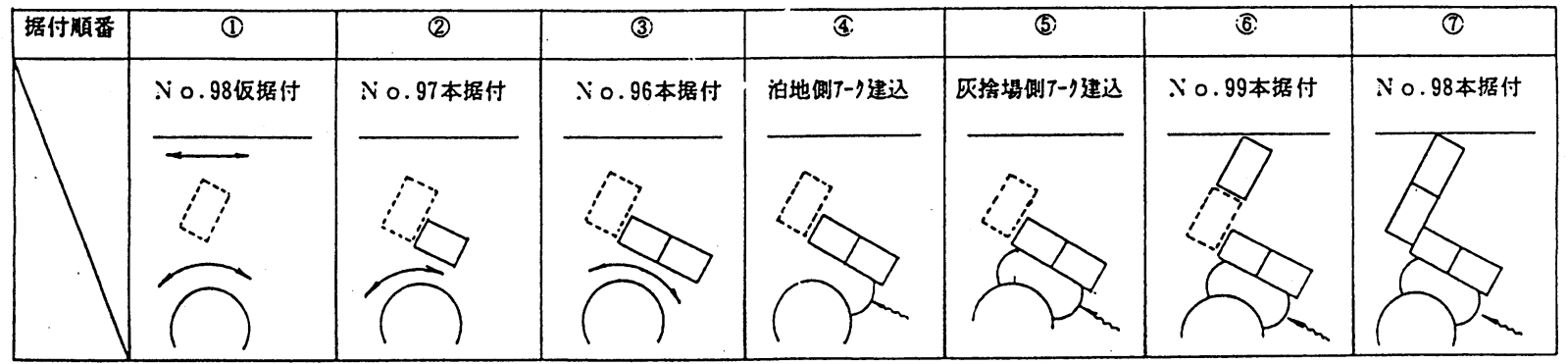

図-5 施工順序

（i）灰捨場全域を対象とする解析領 域（大領域： $1,450 \mathrm{~m} \times 450 \mathrm{~m} 、 \Delta \mathrm{x}$ $=\Delta \mathrm{y}=5.0 \mathrm{~m})$ の締切り外側の境 界条件に、周期 13 分、振幅 $0.1 \mathrm{~m}$ の正弦波を水面変動として与え 解析を行う。なお、水面变動を与 える境界は施工䈉所から約 $250 \mathrm{~m}$ 東側とした。

(i i 格子間隔を小さくした施工箇所 付近の領域 (小領域: $80 \mathrm{~m} \times 80 \mathrm{~m}$ 、 $\Delta \mathrm{x}=\Delta \mathrm{y}=1.0 \mathrm{~m})$ について数值 解析を行う。境界条件は、（i）の 計算で得られた水位変化とする。 （i i i ）施工検討を行うにために、必要な 各地点の流速の時間変化と流速 の平面的な分布などを出力する。

\section{3 解析結果}

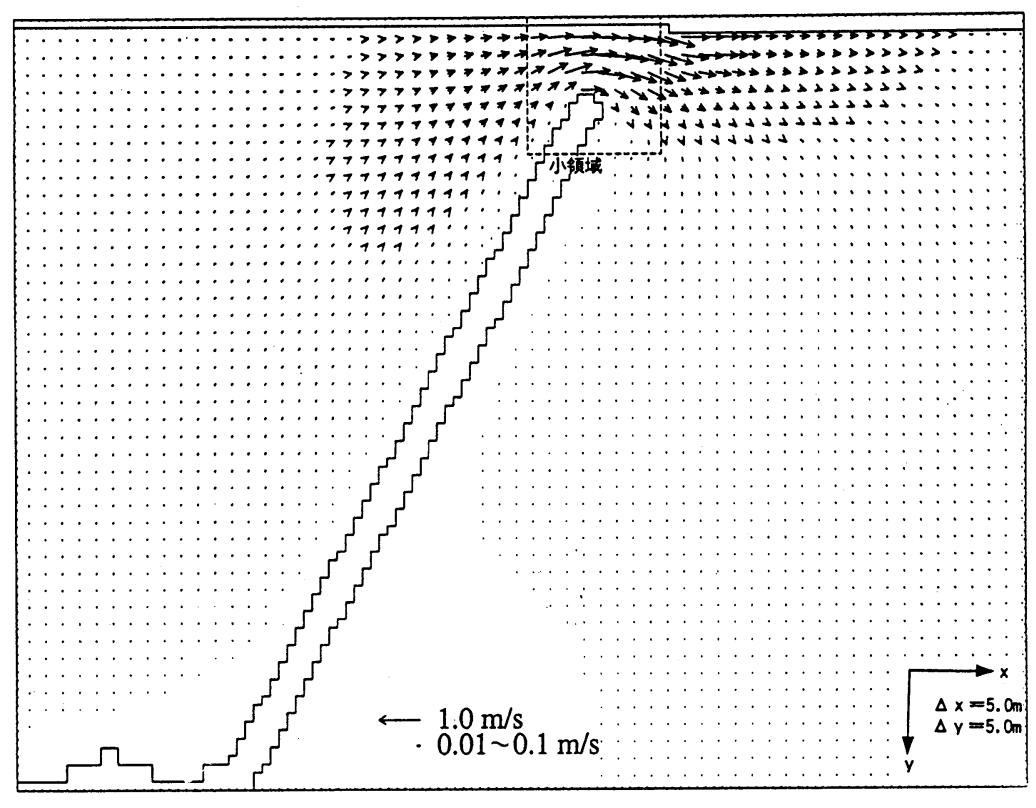

図-6 大領域流速分布（施工前）

図一 6 にケーソン据付け前の、大領域の流速分 布の一例を示す。図示したのは、締切り内から外 への流れが最も速い時刻のものである。北護岸と 北防波堤にそって流出するものが卓越している が、南側へも流出していることが分かる。また、 締切りの内部全体から狭窄部に集中した流れが、 時計方向に回り込むように流出して、拡散してい るようすが分かる。

ケーソン据付け箇所には捨石基礎が既に設置 されており、天端水深は $8 \mathrm{~m}$ と最も浅くなってい る。このマウンド部分で、開口幅の縮小と水深の 低下によって流れが早くなり、摩擦損失等の増大 をもたらすとともに、両海域の海水交換が支配さ れている。図ー6に破線で示した小領域の計算結 果を図ー 7 に示す。小領域の境界に大領域で計算 された水位を与えたが、内外で流速分布がうまく 接続されていることが分かる。狭窄部を通過した 流れは、北護岸に沿いに進んだ後に広範囲に広が るように流出している。

次に、図ー7で示したP 1 P 4 の地点での水面変動 と流速の時間変化を図ー8に示す。同図 $(\mathrm{a})$ の水面変動に 注目すると、小領域の外側にあたる P 4 はノコギリ型の 波形をしており、締切り内のP 3 はほとんど変化を示い ていない。この 2 点の水位差によってP1，P 2 の流れ

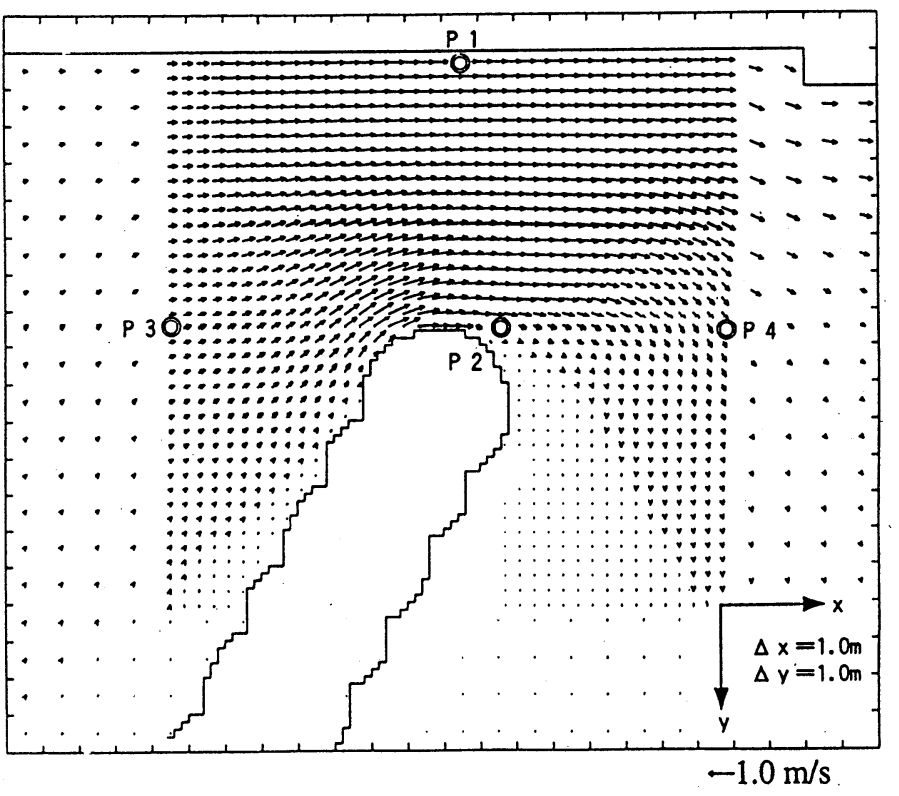

図-7 小領域流速分布（施工前）

表ー 2 施エステップ毎の予測流速

\begin{tabular}{|c|c|c|c|c|c|}
\hline & \multicolumn{5}{|c|}{ 施エステップ } \\
\cline { 2 - 6 } & 施工前 & (1) & (2) & (3) & (5) \\
\hline P 1 流速 $(\mathrm{m} / \mathrm{s})$ & 0.83 & 0.71 & 0.81 & 0.89 & 0.67 \\
\hline P 2 流速 $(\mathrm{m} / \mathrm{s})$ & 0.86 & 0.31 & 0.20 & 0.17 & \\
\hline
\end{tabular}


が発生している。同図 (b)に示す北護岸の前面 のP 1 では北護岸に沿った $\mathrm{x}$ 方向に約 $0.83 \mathrm{~m} / \mathrm{s}$ の流速が予測される。図一 7 の流速べ クトルでも明らかなように、P 1，P 2 では、 北護岸に沿った方向の流れが卓越しており、 Y軸方向の流れはあまり発生しない。P 1 で はX方向の流速が正弦波のような変化を示し ているが、図ー8（c）に示すようにP 2 では締 切り内から外への流速が卓越している。

次に、ケーソンを 2 基据付けた場合（図ー 5 の施エステップ(2)）の小領域での解析による 流速ベクトルを図ー9に示す。狭窄部の中央 を約半分遮る 2 基のケーソンによって、流れ が分断されていることが分かる。その結果、 北護岸に沿った流れはあまり変化しないが、 P 2 側ではその流速が小さくなることが分か る。

\section{4 施工検討}

以上のような方法によって、施エステップご との解析を行い、それぞれの流速を整理した のが表ー 2 である。当初、ケーソンの設置が 進むにしたがって開口部が小さくなるため、 流速が増すのではないかと想定したが、北護 岸側のP 1 については目立った変動はないこ とが分かった。一方、P 2 側は施エステップ (1)でケーソン No.98 を設置した時から流速が 減少することが分かった。これは、鋼板セル と No.96、97 ケーソンの間が約 $6 \mathrm{~m}$ と北護岸側の 開口部に比べて狭いことや、図－6、図ー7など に示すように、北護岸に沿った流れが卓越してい ることなどによるものであると考えられる。

以上の解析結果から、施工時の流速は施工前に 比べてあまり大きく増加しないと考えて、図ー 5 に示した順序で施エすることに決定した。

\section{5. 施工時の流速}

施工に際して再び現地観測を行った。図ー10 に観測装置の配置を示す。水位観測位置を図ー2 に示した位置と変更したのは、クレーン船による 作業の障害になるためである。

図ー 5 の施エステップ(1に相当するNo.98ケー ソンを仮据付け後の観測結果を図ー 11 に示す。 水面変動と同時に最大で $1.0 \mathrm{~m} / \mathrm{s}$ 程度の流速が発 生していることが分かる。また、この間の波形のピーク值を平均すると $0.8 \mathrm{~m} / \mathrm{s}$ 程度となってる。この時点での数 值解析による予測值は表一 2 に示すように $0.71 \mathrm{~m} / \mathrm{s}$ であり、海象の不規則性を考えると妥当な結果といえる。ま た、ケーソンN No.96,97 を施工中とその前後は観測を行ったものの、海象が非常に穏やかで、ほとんど流れは発生 しなかった。同様にして、他の施エステップの施工時の流速も観測したが、施工の障害にならない時間に観測を 行ったこと、工事の進渉が早く十分な観測時間が確保できなかったことや欠測が多かったことなどにより、解析 結果を検証するために十分なデータを収集できなかった。

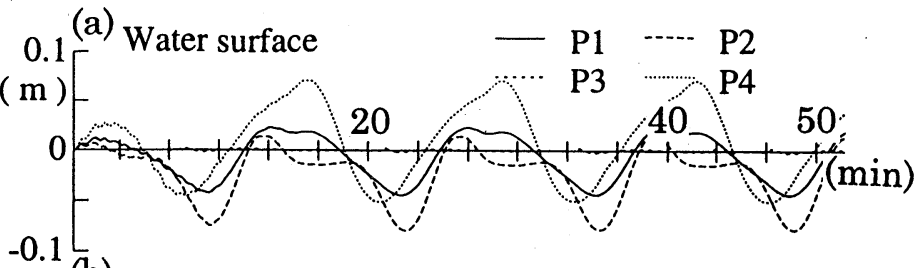

1.0 (b) P1 Velocity

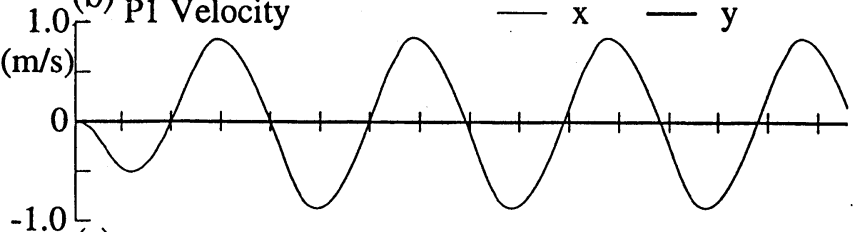

(c) P2 Velocity
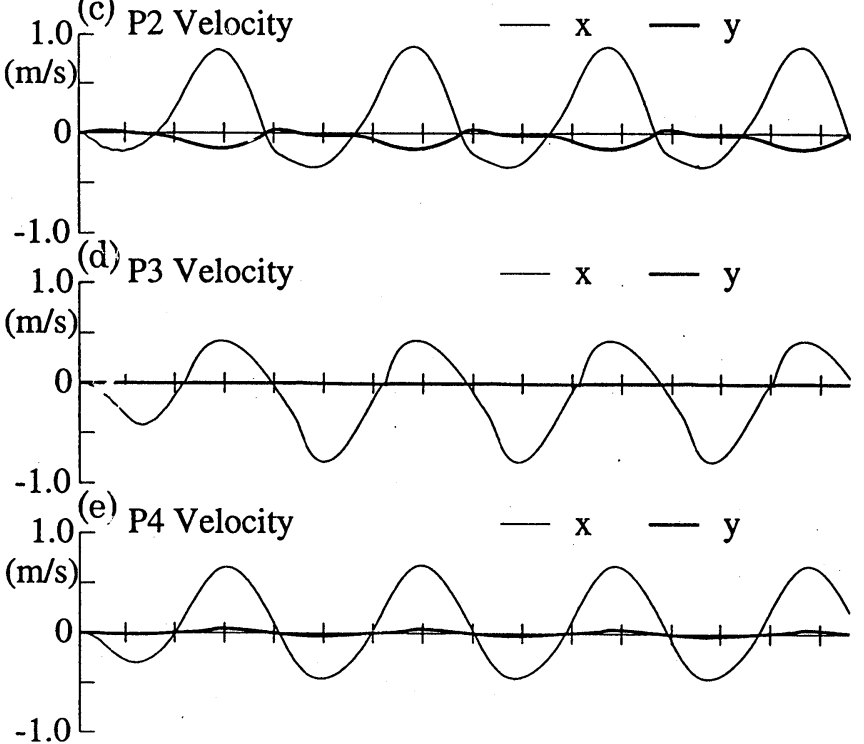

図-8 水面変動・流速の時間変化（施工前）

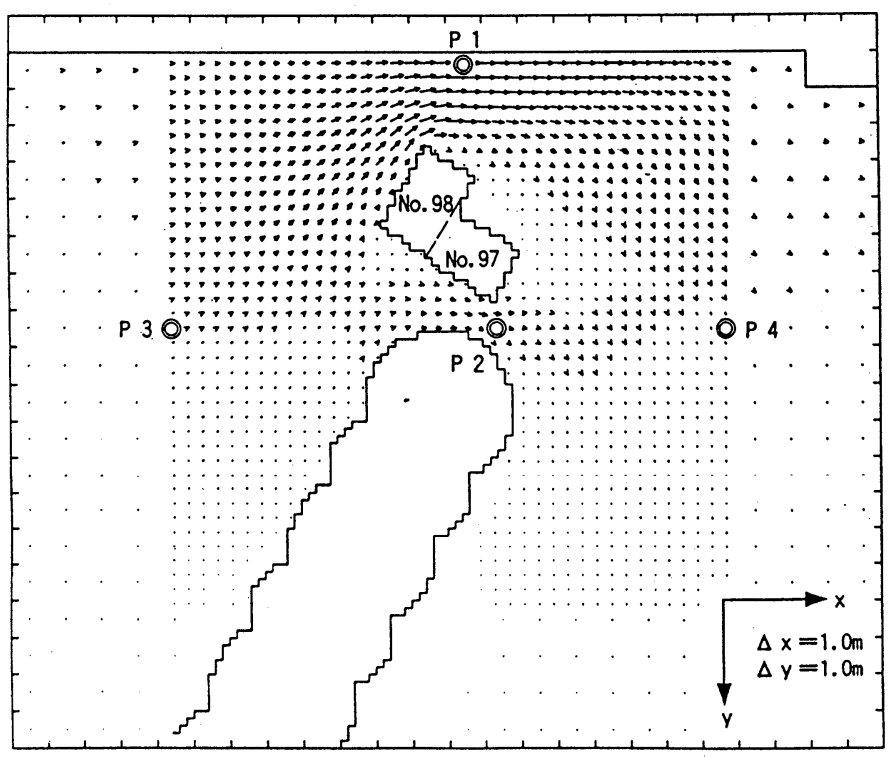

図-9 小領域の流速分布（ステップ(2) 
6.おわりに

ケーソンの設置による海域の流れの変化 について現地観測と数值解析を行った。そ の結果、以下のようなことが明らかになっ た。

（1）現地観測から、灰捨場東護岸と北護 岸の最終締切り部分で、最大 $1.0 \mathrm{~m} / \mathrm{s}$ 程度の流速が観測された。この時、 周期約 13 分、振幅 $10 \mathrm{~cm}$ 程度の長周 期の水面変動が発生している。

（2）ケーソンの設置順序にしたがって数 值解析を行ったところ、ケーソンの 設置に伴って流速がやや上昇する場 合があるものの、施工前を大きく上 回るような流速が発生することはな いと予測された。

（3）ケーソン設置に際して、再び現地観

測を行った。その結果、ケーソン 1 函を仮据 付け後の状況において解析值とほほ等しい流 速が観測された。しかし、施工の進渉が早く 観測期間が短かったことや、海象の不規則性 などから予測していたような水面変動をとら えることができず、その他の施エステップに おいては解析精度の十分な検証ができるよう なデー夕を取得することは残念ながらできな かった。

（4）湾口など長周期の水面変動によって流れが発 生する海域において、浅水長波の数值解析が 工事施工時の流速検討などに役立つことが分 かった。
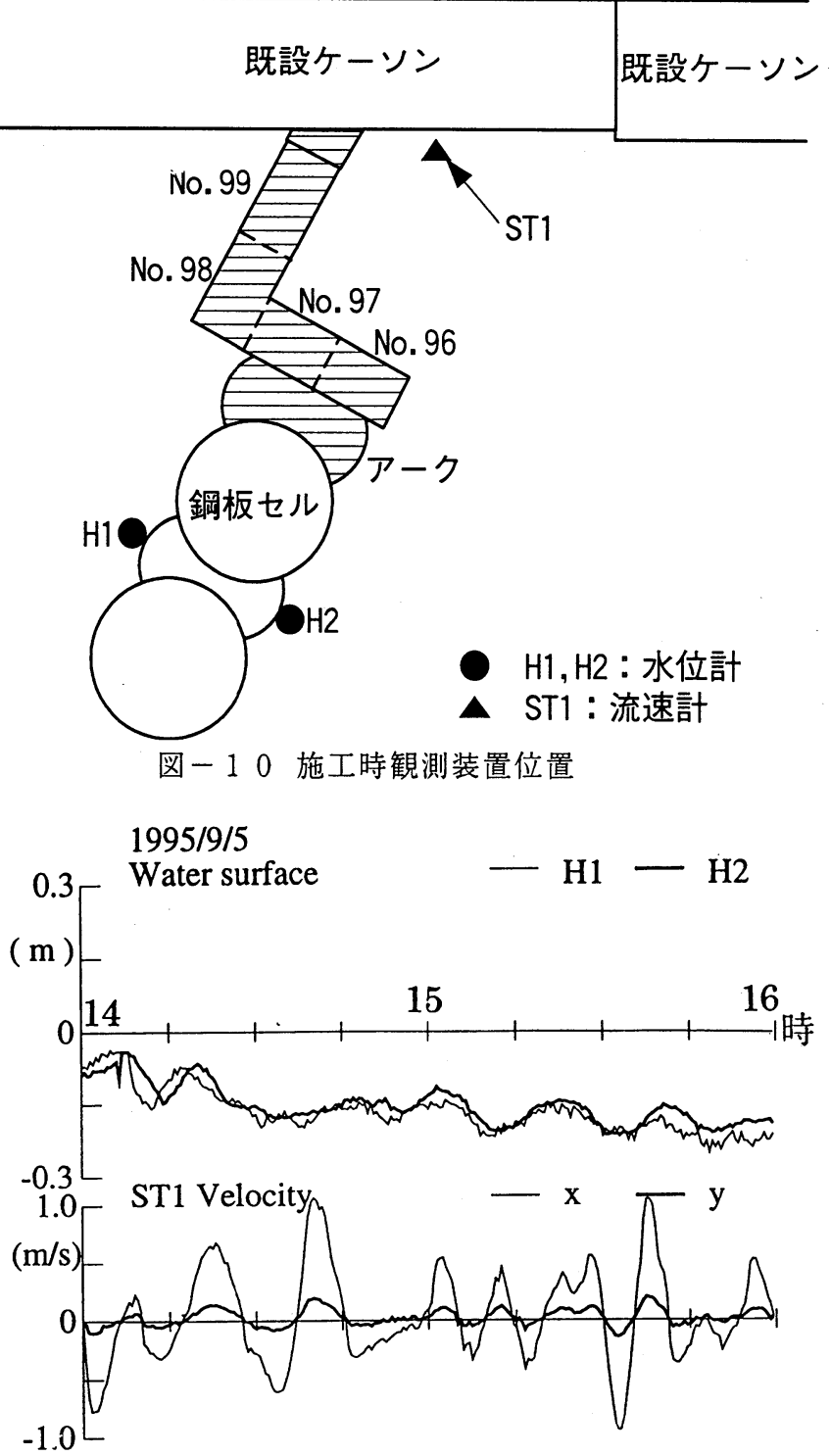

図一-1 1 施工時観測結果

\section{参考文献}

中山哲厳・山本 潤 ·松岡道男 ·池田正德・竹内聖一 ·灘岡和夫 ·八木 宏 (1994)：中小港湾湾口部に発生する水 平大規模渦についての現地観測、海岸工学論文集、第 41 巻、pp. 321-325.

田中寛好・和田 明 (1985): 温排水拡散範囲に及ほす海浜流の影響、電力中央研究所報告、研究報告 $384046 、 55 p$. 